\title{
Implikasies van ontwikkelings in die leerstelling van goddelike genesing binne die Pinksterbeweging
}

\author{
Author: \\ Marius $\mathrm{Nel}^{1}$ \\ Affiliation: \\ ${ }^{1}$ Faculty of Theology, \\ North-West University, \\ Potchefstroom Campus, \\ South Africa \\ Correspondence to: \\ Marius Nel \\ Email: \\ nel.marius1@gmail.com \\ Postal address: \\ PO Box 12373, Bendor Park \\ 0713, South Africa \\ Dates: \\ Received: 22 Dec. 2013 \\ Accepted: 09 May 2014 \\ Published: 08 Sept. 2014 \\ How to cite this article: \\ Nel, M., 2014, 'Implikasies \\ van ontwikkelings in die \\ leerstelling van goddelike \\ genesing binne die \\ Pinksterbeweging', In die \\ Skriflig 48(1), Art. \#1792, \\ 9 pages. http://dx.doi. \\ org/10.4102/ids.v48i1.1792

\section{Copyright:} \\ (c) 2014. The Authors. \\ Licensee: AOSIS \\ OpenJournals. This work \\ is licensed under the \\ Creative Commons \\ Attribution License.
}

Read online:

Scan this $Q R$ code with your smart phone or mobile device to read online.
Die Pinksterbeweging het met verloop van tyd sy begrip van die leer van goddelike genesing verander. Die veranderings is hoofsaaklik as gevolg van vorderings wat deur die mediese wetenskap gemaak is en die pinksterteologie moes opnuut die verhouding tussen versoening en heling definieer. Die veranderings word in terme van die geskiedenis van die wit afdeling van die Apostoliese Geloof Sending van Suid-Afrika (AGS), die grootste pinksterdenominasie in Suid-Afrika, beskryf. Dit dien tot' $n$ groot mate as verteenwoordigend van veranderings in die res van die AGS, maar ook van die Pinksterbeweging as sodanig. Die ontleding toon dat die veranderde houding teenoor die gebruik van medisyne en inenting sowel as mediese prosedures soos operasies pinksterkerke uiteindelik dwing om toegewings in sy genesingsbediening te maak wat aan sy Skrifbeskouing verwant is. Dat die kerk veranderings aanbring in 'n belangrike leerstelling soos dié van goddelike genesing, hou belangrike implikasies vir die kerk in. Die implikasies hou verband met die wyse waarop die pinkstermense die Bybel lees en benut en dit noodsaak die Pinksterbeweging om ook oor ander leerstellings na te dink wat uitdagings daaraan stel, byvoorbeeld die eskatologie en ekklesiologie.

Implications of developments in die doctrine of divine healing in die Pentecostal movement. The Pentecostal movement changed over time its understanding of the doctrine of divine healing. These changes are mainly in the attitude towards the advances made by medical science and reflected in the way pentecostal theology defined the relation between atonement and healing. The changes are described in terms of the history of the white division of the Apostolic Faith Mission of South Africa (AFM), the largest pentecostal denomination within South Africa. It serves to a large extent as representative of the changes in the AFM, but also the Pentecostal movement per se. The analysis shows that the changed attitude towards the use of medicine and vaccination as well as medical procedures such as operations eventually forced pentecostal churches to make concessions in its healing ministry, leading to changes in its scriptural view of the doctrine under consideration. That the church changed in aspects related to such an important doctrine poses important challenges that it must take note of. These implications are related to the way pentecostal people read and use the Bible and require that the church reflect on other doctrines that also challenge the Pentecostal movement, like its eschatology and ecclesiology.

\section{Inleidend}

Praktiese werklikhede het die Pinksterbeweging gedwing om sy weergawe van die leerstelling van goddelike genesing aan te pas en te verander (Anderson 2003:5; Saayman 1993:46). Hierdie artikel ondersoek die historiese ontwikkelings van die leerstelling binne die Apostoliese Geloof Sending van Suid-Afrika (AGS), die grootste pinksterkerk in Suid-Afrika en spesifiek die wit afdeling van die kerk wat teologiese leiding aan die res van die kerk gegee het. ${ }^{1}$ Ontwikkelings binne die AGS kan egter tot 'n groot mate as verteenwoordigend van die Pinksterbeweging beskou word, omdat daar duidelike ooreenkomste in die teologiese ontwikkelings aangetoon kan word. ${ }^{2}$ Die hipotese is dat ontwikkelings in die praktyk van die genesingsbediening die kerk genoop het om binne die spanningsveld van die verwagtings van die lidmate toegewings te maak ten opsigte van sake soos inenting en die houding teenoor die mediese wetenskap. Dit het daartoe gelei dat die kerk nuut oor die verband tussen versoening en genesing moes dink. Dat die kerk 'n leerstelling wat 'n belangrike deel van sy boodskap vorm, verander het, hou belangrike implikasies vir die kerk in waarvan kennis geneem moet word. Die implikasies raak onder

1.Die verwysings is na die bestaan van die AGS in vier afdelings in antwoord op die politieke ontwikkeling van die Suid-Afrikaanse apartheidsbeleid wat eers in 1996 opgehef is toe die kerk verenig het (Burger \& Nel 2008:404-433).

2.Dit val buite die omvang van hierdie artikel om die stelling te staaf dat ontwikkelings in die AGS se verkondiging en praktyk van genesing verteenwoordigend van die Pinksterbeweging is, alhoewel dit vanuit ' $n$ vergelyking van bronne wat binne die Pinksterbeweging gepubliseer is, bewys kan word soos Chappell (1983:1-178) omvattend aandui. 
andere die AGS se Skrifgebruik asook bepaalde leerstellings; dit noodsaak daarom verdere teologiese besinning.

\section{Leerstelling van goddelike genesing soos in die Apostoliese Geloof Sending van Suid-Afrika verkondig en beoefen}

\section{Die rol van genesing in die totstandkoming van die Apostoliese Geloof Sending van Suid-Afrika}

Die AGS het uit die werk wat twee Amerikaanse sendelinge, John G. Lake en Thomas Hezmalhalch, in Suid-Afrika kom doen het, ontstaan. Lake is in 1891 as predikant van die Metodistekerk georden, maar hy het kort daarna die bediening verlaat om ' $n$ lewe in die boubedryf te maak. Sy sterwende broer is onmiddellik ná 'n gebed deur John Alexander Dowie, leier van die Christian Catholic Church in Zion, genees (Chappell 1983:284; Lake 1994:xv-xvi). ${ }^{3}$ Sy suster se genesing van borskanker in antwoord op Dowie se gebed volg 'n paar dae later. Nog 'n suster wat aan 'n ernstige ginekologiese toestand gely het, het egter siek gebly - selfs ná gebed. 'n Desperate telegram na Dowie toe haar siekte 'n ernstige wending geneem het, het daartoe gelei dat sy ook gesond geword het in antwoord op gebed. Kort daarna het Lake se vrou siek geword. Tydens haar versorging het Lake Handelinge 10:38 gelees wat aandui dat Jesus almal genees het wat in die mag van die duiwel was. Dit het Lake laat besef dat Jesus die Geneesheer en Satan die verdrukker is. Hierdie insig het vir hom die sleutelwaarheid van die evangelie geword. Dit het daartoe gelei dat sy so sterk in goddelike genesing geglo het, dat sy in 1900 nadat sy in 'n skietongeluk gewond is, mediese hulp geweier het. In 1901 het Lake na Dowie se Zion City verhuis waar hy as diaken en later as ouderling aangestel is met die doel om hom in die leerstelling van die goddelike genesing te verdiep (Burger 1987:131; Lake 1994:xx). Dowie se finansiële sake het in 1904 as gevolg van wanadministrasie skeefloop, waarop Lake as bestuurder van die kerk se boudepartement en ouderling bedank het (Burger \& Nel 2008:31).

In 1907 het Lake daarvan oortuig geraak dat dit vir 'n gelowige noodsaaklik is om met die Gees gedoop te word (Lindsay 1972:23; Langerman 1983:80). Hy het van hierdie ondervinding verneem uit die getuienis van mense wat Charles F. Parham se Bybelskool in Topeka besoek het. Terwyl hy saam met Thom Hezmalhalch vir 'n siek vrou gebid het, het hy in tale begin praat. ${ }^{4}$ Hy skryf dat die gevolg daarvan was dat hy agtergekom het dat al hoe meer van die karaktertrekke van Christus in sy lewe voorkom (Lindsay 1972:27). Hy skryf ook: 'My nature became so sensitized that I could lay my hands on any man or woman and tell what organ is diseased, and to what extent' (Lindsay 1972:17; Lake 1994:xx).

3.Lake (1994) bestaan uit' $n$ versameling preke van Lake.

4.In die vroeë Pinksterbeweging is spreke in tale as die inisiële teken beskou dat iemand in die Gees gedoop is. Dit was ook die gevolgtrekking van die studente by die Parham-Bybelskol nadat hul die Paping met die Gees ondersoek het, natmik dat tale teken is van geestesdoop (Wigglesworth 2000:384-385). In die kontemporêre Pinksterbeweging is daar meningsverskil oor tale as inisiële teken van die geestesdoop.
In 1907 het Lake sommige van William J. Seymour se dienste by Azusastraat se Apostolic Faith-kerk in Los Angeles bygewoon waar die pinksterbeweging sy eintlike ontstaan gehad het (Dayton 1987:19). Dit het tot 'n vriendskap tussen die twee manne gelei wat voortgeduur het selfs nadat Lake uit Suid-Afrika na Amerika teruggekeer het (Reidt 1981b:18-19). Lake en Parham het ook vriende geraak en as leiers in die Pinksterbeweging het Seymour, Parham en Lake mekaar se lewens vir baie jare beïnvloed (Burger 1987:132).

In April 1908 het die Lake- en Hezmalhalchgesinne na Suid-Afrika vertrek en kort nadat hulle in Johannesburg ingetrek het, nooi die Sionistegemeente in Breestraat 88 hulle om die eredienste te lei (Lake 1983:33; Horn 1984b:3-4). Hierdie Sionistegemeente is deur Daniel Bryant, Dowie se sendeling na Suid-Afrika, gestig. Feitlik oornag het die Sionistegemeente in 'n Pinkstergemeente verander toe talle lidmate die geestesdoop met die gepaardgaande spreke in tale ervaar het (Du Plessis 1984:40).

By die eerste diens wat die twee Amerikaners gehou het, is die swart werknemer van 'n welgestelde gesin genees. Hierdie gebeurtenis was volgens Burger (1987:167) soos die spreekwoordelike vonk in 'n kruitvat. Talle vroeë lidmate het getuig dat hulle by die AGS aangesluit het nadat hulle genesing ná gebed ontvang het (Burger 1987:178). In 1911 skryf Lake dat daar binne drie jaar 2023 bevestigde gevalle van genesing onder hulle bediening in Suid-Afrika voorgekom het (Burger 1987:177).

Die genesingsbediening het egter ook probleme opgelewer. Uit die Notule van die Uitvoerende Raad ${ }^{5}$ (AGS 1909) van 22 Januarie 1909 kom die volgende saak onder bespreking: 'n broer Schneidermann onttrek hom van die Sending omdat 'a great deal of very sad exaggerations in cases of healing had been made' en boodskappe is aan God toegeskryf wat duidelik nie van Hom kom nie (skynbaar omdat dit nie bybelsbegrond is nie). Hy skryf dat hierdie gedrag nie tot eer van God is nie. Die Raad bespreek die saak in diepte en besluit dat die brief baie waarheid bevat. In die toekoms sou die kerk die uiterste sorg neem dat alles uitgewan word wat nie van God is nie en die predikers sal in die openbaar erken dat hulle foute gemaak het, al kos die belydenis vernedering vir die mense wat daarby betrokke is.

Op 23 Desember 1908 sterf Lake se vrou onverwags, waarskynlik aan 'n hartaanval (Burger 1987:147).

As gevolg van Lake en Hezmalhalch se invloed het die AGS van meet af sterk klem op goddelike genesing ${ }^{6}$ geplaas naas die praktyk om vir mense te bid sodat hulle die doping in

5.Die AGS funksioneer vanaf 1908 tot 1996 met ' $n$ Werkersraad en 'n Uitvoerende Raad. Die Werkersraad het uit alle heeltydse werkers asook afgevaardigdes van gemeentes bestaan en hulle het jaarliks byeengekom om oor gemeenskaplike sake asook kerkordelike reëlings te besin. Die Uitvoerende Raad het uit die vier ampsdraers van die kerk bestaan en is vierjaarliks deur die Werkersraad verkies, saam met die voorsitters van die geografiese distrikte waarin die kerk opgedeel was (Burger \& Nel 2008:82).

6.Pinksterkerke gebruik geloofsgenesing, gebedsgenesing en goddelike genesing as wisselterme, met die klem op geloofsgenesing. Lake, daarenteen, gebruik in navolging van Dowie en Murray uitsluitlik die term goddelike genesing ( $N$ el 1992:139). Die motivering is dat die klem in die genesingsbediening op Gosing (Ne 1992:139). Die motivering is dat die klem in die genesingsbediening op God se werk aanvaar tot vandag toe geen ander term nie (Hanekom 1985:iv-viii). 
die Gees met die gepaardgaande spreke in tale kon ontvang. Lake is op sy beurt sterk deur Dowie asook Andrew Murray in sy genesingsteologie beïnvloed (Lindsay 1949:125).? Die beginsels van Lake se genesingsteologie word soos volg saamgevat (vgl. Burger 1987:177-178): Die basiese uitgangspunt is dat siekte van Satan afkomstig is en dat God niemand siek wil maak of siek wil sien nie (vgl. Lake 1994:143-153 wat in hierdie verband 1 Joh 4:4; Luk 10:19; 2 Tim 1:7; Matt 10:1; 17:20; Ef 4:27; 6:11; Jak 4:7; 1 Kor 10:13 bespreek). Siekte bring geen eer aan God nie, terwyl genesing dit wel doen (vgl. Lake 1994:419-425 wat in hierdie verband Ps 103:2-3; Matt 4:23; 8:1-8, 17; 10:1; Jes 35:5-6; Luk 9:6, 11; Joh $5: 14 ; 1$ Pet 2:24 bespreek). Die Bybel bring siekte in verband met Satan en sy demoniese magte. ' $n$ Tweede beginsel is dat dit God se wil is om genesing aan sy siek kinders te skenk, volgens die beloftes wat Hy in die Bybel maak (vgl. Lake 1994:173-181 wat ten opsigte hiervan Luk 11:1-4; Matt 8:2; 26:39; Hand 8:3; Mark 11:24; Jak 1:7 bespreek). 'n Derde beginsel lê die klem op die mens se geloof as voorwaarde dat genesing ontvang word. Die feit dat gelowiges nie gesond word nie, staan in direkte verband met die sieke sowel as die genesingsbedienaar se ongeloof (vgl. Lake 1994:407-412 wat hieroor Mark 16:15-16; Op 1:18; en Rom 10:9-10 bespreek).

Lake (Reidt 1981a:32; 1989:114) ${ }^{8}$ definieer goddelike genesing as die verwydering van siekte deur die krag van God; die proses of daad van God waardeur Hy die beskadigde liggaam van sy kind, wat die tempel van sy Gees is, herstel deur die vreemde oortreder, Satan en sy demone, te verjaag. ${ }^{9}$ Goddelike genesing is die definitiewe werking van die Gees in die lewe van mense (Lake 1954b:15). Goddelike gesondheid volg wanneer gelowiges daagliks in kontak met God leef sodat sy lewe deur hulle vloei en heelheid bring. ${ }^{10}$

Goddelike genesing is die bewys aan die wêreld dat Jesus die Seun van God is (in navolging van Matt 11:3-6). Daarom is goddelike genesing as evangelistiese middel waardevol, want dit trek mense deur tekens en wonders (Reidt 1981a:37). In sy dienste benut Lake die demonstrasie van goddelike genesing om besoekers onder die oortuiging van die krag en werklikheid van God te bring. Goddelike genesing

7.Lake maak baie gebruik van Murray se werk, Jezus, de Geneesheer der kranken (1884; in Engels vertaal as Divine healing 1982) en The Lord thy Healer (1894; vgl. Douglas 1926:192-198; Choy 1978:199). Hy verwys ook na Dowie se preke waarna hy geluister het, asook Dowie se gepubliseerde werke, Rome's polluted springs (1877) asook The drama, the press and the pulpit (1879). Lindsay $(1949 ; 1971 ; 1976)$ bevat preke van Lake wat bewaar gebly het en die preke vorm naas enkele briewe die enigste skriftelike materiaal wat van Lake oorgelewer is.

8.Reidt (1981a) bevat preke van Lake wat bewaar gebly het.

9.Lake (aangehaal deur Liardon 1996:173) beklemtoon dat dit die duiwel en sy magte is wat agter die verwoestingswerk in die wêreld sit; siekte val ook hieronder. Hy baseer dit op Handelinge 10:38, naamlik dat mense wat siek is, deur die duiwe verdruk word en dat Jesus gekom het om hulle van hierdie mag te bevry. 'Those powerful words ripped through his thoughts. "OPPRESSED OF THE DEVIL!" Tha meant that God wasn't the author of Jennie's sickness, or any sickness! And if Lake was a son of God through Jesus Christ, then God was with him, just as He was with Jesus! Now he was convinced that it was the devil who had caused Jennie's illness. It was the devil who was stealing the mother of his children. It was the devil who was destroying his life!' Jennie was Lake se vrou wat ernstig siek was.

10.Lake (1994:435) skryf dat God se doel is om in die aard van die mens' $n$ bewustheid van God te skep wat toelaat dat sy Gees oomblik-vir-oomblik deur' $n$ mens vloei. Dit laat die mens ook nuut leer dink en sensitiveer die mens vir die leiding van die Gees.Dit wil ook die mens se liggaam direk onder beheer van die Gees stel. Wanneer die mens God se wil ook ten opsigte van die liggaam doen, vloei daar genesing voort (Lake 1994:444). bewys dat die Here teenwoordig is en 'n mag is waarmee die mens rekening moet hou (Reidt 1981a:1). Wonderwerke is 'God intervening in the general order of things to meet a need by supernatural means or power' (Reidt1981a:1).

Siekte is die eerste aanduiding dat die dood uiteindelik gaan toeslaan en dood is die gevolg van sonde. Daarom is daar geen siekte in God nie en die mens voor die sondeval het ook nie siekte geken nie. Deur sonde het die God-mens nou aarde-mens geword en daarom is sonde die oorsprong van siekte (Reidt 1989:108). ${ }^{11}$ Wanneer siekte geanaliseer word, is sonde meestal die oorsaak, redeneer Lake (1994:385). Dit is nie noodwendig 'n daad van persoonlike sonde nie, maar meer dikwels sonde wat met die luiheid van die siel, passiwiteit van die gees, of die versuim om die Bybel te bestudeer, te glo, te bid of liefde te betoon te make het (Lindsay 1949:54). Die korrekte benadering tot siekte is dieselfde as dié tot sonde, naamlik om dit as iets haatliks te beskou wat bestraf, uitgewerp en vernietig moet word. Dit is ook Jesus se houding teenoor siekte (Reidt 1981a:167).

Lake onderskei tussen siekte van die liggaam, die siel en die gees. ${ }^{12}$ Die basiese siekte is siekte van die gees en genesing van die gees lei tot genesing van die liggaam (Lindsay 1971:37). Elke fisiese verandering in die liggaam kan na 'n geestelike toestand teruggespeur word (Lindsay 1971:37). Lake (1968:5) skryf in sy dagboek van 'n vrou met'n verlamde arm wat deur die dokters gediagnoseer is as die gevolg van 'n klierinfeksie. Hy het vir haar gebid en alhoewel die pyn opgehou het, het die genesing van die klier en die arm nie plaasgevind nie. 'Ons sal weer moet gaan want daar was iets geesteliks in verband met haar wat nie duidelik was nie', is sy bevinding.

Lake beskou goddelike genesing as ' $n$ integrale deel van die heil wat God in Christus aan die mens bied. Heil is inklusief van alles wat God vir die mens wil doen (Lindsay 1976:19). God vergewe die mens op grond van Jesus se kruisdood en wanneer Hy die mens gesond maak, is dit 'n demonstrasie dat die sonde ook vergewe is (Lindsay 1949:17). Sondebelydenis behoort daarom altyd die gebed om genesing vooraf te gaan (Lake 1960:17). Genesing is deel van die heil wat God in Christus aan die mens skenk.

Lake (Reidt 1981a:54-55, 98) maak 'n duidelike onderskeid tussen siekte aan die een kant en lyding of die verdrukking wat Christene ly omdat hulle hulle getuienis getrou uitleef, aan die ander kant. Lyding behels vals beskuldigings, vervolging, verlies van besittings en skipbreuk wat die Christen ter wille van die evangelie beleef. Siekte daarenteen, kom direk van Satan en is nie God se wil vir die gelowige

11.Lake ontwikkel ' $n$ eie woordeskat om na die nuwe mens te verwys, naamlik die mens met ' $n$ nuwe bewussyn en wat deur die Gees gelei word.

12.Lake neem die Pauliniese taalgebruik van Paulus in 1 Tessalonisense 5:23 oor sonder om eksplisiet te verduidelik hoe siel en gees aan mekaar verwant is. Met gees verwys Lake waarskynlik na die mens se vermoë om in' $n$ verhouding met God te staan, terwyl siel na die vlees of sondige natuur van die mens verwys. Christus het gekom om die mens in alle aspekte van menswees te genees, want 'as $\mathrm{He}$ is, so het gekom om die mens in alle aspekte van menswees te genees, want 'as He is, so
are we in this world' (Lake 1994:62). Dit impliseer dat die heerlikheid en krag van Jesus die mens se eiendom word en die mens na liggaam, gees en siel heelmaak. 
nie. 'Never did Jesus tell a person that he must remain sick', preek Lake (Reidt 1981a:56). Paulus se doring in die vlees het met vervolging ter wille van die evangelie te make, nie met siekte nie (Reidt 1981a:96). Lyding kan deel van die leer- en opleidingsproses wees waardeur God sy kinders se karakter vorm, maar siekte kom nooit in Jesus se liggaam voor nie, alhoewel die Seun gehoorsaamheid geleer het deur wat Hy gely het (Heb 5:8; Reidt 1981a:36). 'n Goeie vader straf nie sy seun deur siekte of ongelukke oor hom te bring nie; indien siekte van die duiwel afkomstig is om God se werk te vernietig, gaan God verseker nie die duiwel gebruik om sy werk in sy kinders te volvoer nie (Reidt 1981a:87). As mense glo dat God siekte gebruik om sy werk in hulle lewe te doen, waarom hardloop hulle dan dokter toe om die 'seën van God' verwyder te kry, vra Lake (Reidt 1981b:62).

Lake (Reidt 1981a) handhaaf 'n radikale standpunt teenoor die mediese wetenskap:

It is not my purpose to degrade medical practice. It is man's best effort to lift himself out of the mess Adam brought upon the race by his high treason. I only wish to present God's better way. (p. i)

Dit is ' $n$ sonde van ongeloof om dokter toe te hardloop wanneer jy siek is, meen hy, 'a violation of your consecration to God' (Reidt 1981a:121). Siekte wil die mens op die plek bring waar jy ootmoedig na God roep en jou afhanklikheid van Hom bely, maar deur die dokter te raadpleeg, kom die mens nie op daardie plek nie, soos Asa se geval demonstreer (2 Kron 16:12; Lake 1954a:21 verwys verkeerdelik na Hiskia as die koning wat in sy siekte nie die Here geraadpleeg het nie). Op hierdie manier stel gelowiges hulself vir vreemde magte oop, spesifiek vir die 'little medicine god behind the door' (Lindsay 1949:42). 'Drugs have always been the unbeliever's way of healing. God always was and is the real Christian's remedy' (Lindsay 1949:43). Selfs aan die kruis weier Jesus 'n pynverligter, volgens Matteus 27:34 (Reidt 1981a:47). 'Throw your medicine in the toilet, and then apologize to the toilet', leer Lake (Reidt 1989:53).

Nadat Lake in Februarie 1913 na die VSA teruggegaan het, het Pieter L. le Roux die AGS verder gelei en hy gaan voort om genesing te beklemtoon. ${ }^{13}$ Le Roux het hom as onderwyser by Andrew Murray (jnr.) se Sendingseminarium op Wellington bekwaam met die doel om sendingwerk te doen nadat hy onder Murray se bediening tot bekering gekom het. Murray en Le Roux het lewenslange vriende gebly. 'The relationship between these two men is one of the subtle turning-points in South African church history', is Sundkler (1976:14) se opinie. Le Roux se bediening het in 1893 in Zoeloeland begin en vandaar is hy na Wakkerstroom waar hy teruggaan en 'n groot impak gemaak het. Le Roux is in 1903 uit die Nederduitse Gereformeerde Kerk geskors oor sy sienings rakende goddelike genesing (wat Murray se standpunt verteenwoordig het). ${ }^{14}$ In Maart 1903 het Le Roux

13. Hezmalhalch het reeds teruggegaan na Amerika ná ongelukkigheid tussen hom en Lake ontstaan het. Dit is nie bekend wanneer hy terug is nie (Burger 1987:158).

14.In die twintigerjare van die vorige eeu skryf S. Stuart van die AGS se Krugersdorpgemeente: 'The Pentecostal movement in South Africa began long before the advent of Lake and Hezmalhalch. The man who started the Pentecostal Work in South Africa, in spite of his "Church" was our South African Saint, Dr Andrew Murray ... I know no better exposition of this vital doctrine (goddelike Andrew Murray ... I know no better exposition of this vital doctrine (goddelike
genesing) ... Have you read his books? They are full of Holy Ghost teaching based genesing) ... Have you read his book
on the Bible' (Stuart 1935:24). by Daniel Bryant se Sionistebeweging aangesluit (Sundkler 1976:28). Driekwart van sy gemeente het hom na die Sioniste gevolg en toe Le Roux in 1908 by die AGS ingeskakel het, was dit vir sy volgelinge ' $n$ krisis en hulle het geweier om Zion uit hulle nuwe naam weg te laat. Die Uitvoerende Raad van die AGS het toestemming verleen dat die Wakkerstroomgroep bekend mag staan as die Siontak van die AGS. ${ }^{15}$

In Le Roux se tyd het die Spade Reën van die AGS weggeskeur onder leiding van Maria M. Frazer oor die beweerde koudheid onder die lidmate, as gevolg van wêreldgesindheid wat in die kerk ingesluip het en wat die vloei van die geestesgawes sou stuit (Burger 1987:248-249; Horn 1984a:5). Een van die klagtes was dat genesing al minder in die AGS voorgekom het.

\section{Houding jeens die mediese wetenskap}

In 1917 het 'n ouerpaar van die Krugersdorpgemeente mediese hulp aan hulle kind geweier en ná die kind se dood is die ouers van strafbare manslag aangekla as gevolg van hulle 'wilful neglect of their child because they refused medical aid and refused to use medicines' (AGS 1918). ${ }^{16}$ Die egpaar is skuldig bevind en die Uitvoerende Raad van die AGS het op 14 Desember 1917 besluit om teen die uitspraak te appelleer, maar hierdie appèl het nie geslaag nie. Die kerk het daarop gereageer deur by sy Algemene Konferensie van 28 Maart tot 07 April 1918 lidmate aan te moedig om 'n petisie te onderteken wat vra dat die regering 'n amendement in die Kinderbeskermingswet aanvaar wat voorsiening maak vir 'n gewetensklousule wat burgers vryskeld 'from use of medicines etc. to those who belong to a Recognised religious body against whose faith it is to use medicines' ${ }^{17}$ Terselfdertyd is lidmate versoek om 'n bydrae tot die hofonkostes van 150 pond te maak (AGS 1918).

Op 23 Maart 1932 het die Uitvoerende Raad 'n soortgelyke geval bespreek toe 'n Francis-egpaar van die gemeente in Port Elizabeth ook aangekla is omdat hulle mediese hulp aan hulle baba geweier het; hulle is aan manslag skuldig bevind en met tien pond beboet. Die AGS het die regering weereens versoek om 'n gewetensklousule in die betrokke wet in te bou, maar sonder enige sukses, selfs nie eers nadat 'n AGSafvaardiging, bestaande uit pastore De Vries, Poggenpoel en Coates, die Minister van Justisie besoek het nie (AGS 1932).

Aangesien die wetgewing burgers verplig het om hulle kinders in te ent, het die AGS se Uitvoerende Raad (AGS 1919b) op 18 Oktober 1919 besluit om lidmate van 'n sertifikaat te voorsien wat die standpunt van die AGS rakende medikasie en inenting verduidelik. Die Minister van Binnelandse Sake is ook skriftelik versoek om lidmate

15.Toe Le Roux in 1913 verplig was om na Johannesburg te verhuis omdat hy as leier van die AGS beroep is, het sy werk sodanig versplinter dat dit in talle swart onafhanklike of inheemse kerke uiteengevloei het (Sundkler 1976:43-67 bespreek die versplinterings).

16.Die Algemene Konferensie het jaarliks met die Werkersraad se vergaderings saamgeval en het ook vergaderings gehou waartydens alle lidmate genooi is om deel te neem.

17.Daar was ook ander godsdienstige groeperings wat die sentiment van die AGS gedeel het en hulle eie petisies aan die regering gerig het, hieronder was die Sewendedag Adventiste. 
van inenting vry te stel. Op 11 Desember 1919 het die Uitvoerende Raad gehoor dat die Departement van Gesondheid ' $n$ brief in respons gestuur het wat die kerk meedeel dat niemand van inenting vrygestel gaan word nie en dat die sertifikaat wat die kerk uitgereik het, geen erkenning geniet nie (AGS 1919c). Die brief vermeld egter ook dat die Staat tot op datum geen dwingingsmag teen lidmate gebruik het nie.

'n Verslag aan die Algemene Konferensie op 16 Julie 1919 (AGS 1919a) meld dat die Verkose Komitee vir Gesondheid by die Parlement aanbeveel het dat 'n klousule vir gewetensbeswaardes ingevoeg word. Die Volksraad het wel die aanbeveling aanvaar, maar die Senaat het dit afgekeur, wat impliseer dat die klousule nie aanvaar is nie.

Die Algemene Werkerskonferensie het op 01 Augustus 1921 gehoor dat die Eerste Minister, Generaal Jan Smuts, negatief op die kerk se vertoë vir 'n gewetensbeswaarklousule in die wet gereageer het, maar dat hy onderneem het dat die wet nie streng op gewetensbeswaardes toegepas sal word nie (AGS 1921).

'n Volgende probleem het ontstaan toe die Suid-Afrikaanse Spoorweë sy werknemers verplig het om aan sy siekefonds te behoort en die kerk gevra het dat sy lidmate hiervan vrygestel word omdat hulle nie van mediese dienste gebruik maak nie. Die versoek het egter geen vrug opgelewer nie.

Terselfdertyd het die kerk vir siek mense gebid en daar was in byna elke uitgawe van die kerk se tydskrif getuienisse van mense wat ná gebed gesond geword het.

'n Nuwe wending het in die dertigerjare van die vorige eeu gekom toe die AGS in 1935 vir die eerste keer toegegee het dat gelowiges siek kan word en nie altyd genesing ná gebed ontvang nie. In die kerk se amptelike blad verwys Jones (1935) na Epafroditus en Trofimus wat skynbaar nie genees is nie en hy erken dat die praktyk toon dat sommige gelowiges vandag nie gesond word deur gebed nie. Die artikel sluit af met die volgende gevolgtrekking:

We do not refuse to consider present-day exceptions, but we do refuse to interpret the Scriptures by present-day exceptions. Salvation is for all, yet all are not saved! The Baptism of the Holy Ghost is for all God's children, yet all God's children have not the baptism in the Holy Ghost. If we accept this, why should we experience difficulty in believing that healing is for all, yet all are not healed. ${ }^{18}$ (pp. 7-8)

'n Klagte wat al meer in die notules van die AGS opgeduik het, is dat tekens en wonders wat die vroeë dae van die kerk gekenmerk het, al skaarser geword het. Verskeie lidmate het hulle kommer uitgespreek dat die AGS 'wêrelds' begin raak het, die 'vuur van die Gees' verloor het en dat geestesgawes al minder voorkom - hieronder het die charisma van genesing

18.Die eerste argument, naamlik dat saligheid aan alle mense aangebied word, maar dat nie almal dit aanvaar nie, is nie geldig nie. Vir pinkstermense het dit met die dat nie almal dit aanvaar nie, is nie geldig nie. Vir pinkstermense het dit met die
vrye wil van die mens te doen om vir of teen die aanbod van saligheid te kies, vrye wil van die mens te doen om vir of teen die aanbod van saligheid te
terwyl genesing uitsluitlik aan die werking en wil van God toegeskryf word. geval (vgl. as een voorbeeld die mededeling oor die besluite van die Werkersraad hieroor in die kerk se blad, Trooster en Boodskapper van Hoop, in 1939:8). Dieselfde klagte het tot die Spade Reën-skeuring gelei.

\section{Bybelse begronding van genesing}

Wanneer die AGS oor goddelike genesing skryf, word talle Skrifverwysings gebruik om die leerstelling bybels te begrond. ${ }^{19}$ Nêrens egter wend 'n skrywer (of predikers) enige poging aan om die Skrifgegewens te verwerk en te sistematiseer om by 'n teologiese refleksie uit te kom nie. Die kerk se Skrifbeskouing is gekenmerk deur die siening dat bybelse gebeure en ervarings bedoel is om net so in die moderne kerk gerepliseer te word. ${ }^{20} \mathrm{Al}$ wat van lidmate verwag word, is dat hulle glo dat God wat in die tyd van die Bybel opgetree het en ondernemings teenoor mense en groepe gemaak het, dieselfde vandag wil en sal doen.

Die Skrifbeskouing word deur verbale inspirasie en 'n literalistiese uitleg gekenmerk. ${ }^{21}$ Godet (1936:25) beskryf byvoorbeeld die Bybel as ' $\mathrm{n}$ dokument 'inspired, word for word, ... no word in it save such as God has selected ...'. De Vries (1938a:20) skryf: 'Die Bybel is die geïnspireerde Woord van God, en daarby 'n onfeilbare reël van geloof en gedrag hoër as ons gewete en verstand (2 Tim 3:15-19; 1 Pet 3:23-25; 2 Pet 1:19-20; Heb 4:12; Matt 5:17-18).' Dit bied 'n voorbeeld van Skrifgedeeltes wat goedskiks langs mekaar geplaas is, terwyl dit nie eens na dieselfde aspekte verwys en een argument dien nie. Matteus 5 handel byvoorbeeld oor die geldigheid van die wet en die profete - Jesus het nie gekom om dit ongeldig te verklaar nie, maar om dit te vervul of hulle hulle volle betekenis te laat kry; 2 Timoteus 3 handel oor die waarde van die (Hebreeuse) Bybel as toerusting vir die man van God wat in God se diens staan; 2 Petrus 1 gaan oor profesie as openbaring van God (profesie word deur die pinkstermense as 'n verskynsel beskou wat in die gemeente voorkom en waar lidmate onder inspirasie van die Gees 'n boodskap oordra); en Hebreërs 4 verwys na die snyvermoë van die Woord om die mens se hart te ontbloot. De Vries gebruik dit as 'bewysplase' dat die hele Bybel deur God geïnspireer is en as 'n onfeilbare maatstaf en reël geld. In 'n ander artikel noem De Vries (1938b:3) dat die Bybel die wil van God rakende siekte en genesing bevat, wat vir alle tye op alle gelowiges van toepassing is en dat die mens se optrede in tye van siekte ook daaruit afgelei kan word. Skrifgedeeltes word op alle mense se lewensituasies toegepas.

Deur die Bybel so te interpreteer, word die uitsprake van Jesus en die apostels oor die gewilligheid van God om

19.Nelson (1936:23) skryf oor tien instruksies aan mense wat genesing soek en hy verwys na 55 tekste sonder om een daarvan in terme van konteks en gebruik in die tyd waarin dit ontstaan het, te bespreek.

20.Die kerk werk egter eklekties met die Skrif, sodat dit sommige optredes en ervarings waarvan die Bybel melding maak, ignoreer. Die kerk pas uit die Bybel net toe wat paslik is.

21.'We believe that the Bible is the word of God, written by men as the Holy Spirit inspired them. We believe that it authoritatively proclaims the will of God and teaches us all that is necessary for salvation' (Artikel 5; AGS 2013). 
te genees, kategories gelees en van toepassing gemaak op almal wat gelowig daarvoor vra. Hieruit word dan die afleiding gemaak dat God almal, te alle tye en in alle omstandighede, gesond wil maak. 'n Implikasie hiervan is dat geen gelowige dan sterf deur eers siek te word nie. Op hierdie manier word God as 't ware 'n gevangene van die Woord gemaak en gelowiges bind die Here aan sy Woord sodat Hy verplig is om te doen wat Hy belowe het. ${ }^{22}$ So 'n aanmatigende houding laat nie ruimte vir die soewereine besluite wat God in sy almag en alwysheid oor elke individu neem nie; dit gee ook nie erkenning daaraan dat God 'n unieke pad met elke gelowige loop nie. God word hierdeur 'n gevangene van die mens se Skrifgebruik gemaak.

\section{Nuwe pragmaties-teologiese fundering van genesing}

F.P. Möller was vanaf 1950 prinsipaal van die Apostoliese Bybelkollege en het in 1954 'n binnemuurse afdeling gestig. Hy is in 1955 as hoof van publikasies aangestel en in 1958 as sendingsuperintendent voordat hy as hoofsekretaris in 1962 en as president van die AGS in 1966 gekies is - ' $n$ pos wat hy tot 1988 beklee het (Jooste s.a.:22-76).

Möller het die spanning in die AGS sien opbou rondom gemeentes wat 'n meer rustige liturgie ontwerp teenoor die lawaaierige eredienste wat die vroeë jare van die kerk se bestaan gekenmerk het - in die lawaaierige eredienste bid mense hardop en praat in tale, klap hande en dans en opper die klagte dat die 'Nuwe Orde'23 wêreldgesindheid in die kerk indra en die werking van die Gees uitdoof en verwaarloos. Die klagte kom al meer voor dat genesings 'n uitsondering geword het terwyl dit in die vroeër jare die norm was. Hieruit ontstaan die Pinkster Protestantse Kerk (PPK) toe die AGS op 10 Oktober 1958 skeur, hoofsaaklik as gevolg van spanning oor die nuwe rigting waarin die AGS onder dr Möller se leiding beweeg, maar ook vanweë 'n leierskapstryd (Burger 1987:316-350 beskryf die skeuring vanuit die perspektief van die AGS). ${ }^{24}$

In hierdie tyd het die kerk se standpunt ten opsigte van mediese hulp verander. Die historiese konteks hiervan moet

22. Hierteenoor stel Karl Barth (1957:527) dat die Woord van God, sy openbaring aan die mens, altyd 'n nuwe werk is, ' $n$ vrye besluit van God wat nie deur die skepse in diens geneem kan word nie. Die Woord behoort nooit aan die geskiedenis nie, maar is altyd ' $n$ eksterne gebeure wat mense in hulle kontemporêre bestaan nie, maar is altyd ' $n$ eksterne gebeure wat mense in hulle kontemporere bestaan aanraak en tot ' $n$ antwoord uitdaag (Barth 1957:528). Bart (1957) stel: "If therefore we are serious about the fact that this miracle is an event, we cannot regard the presence of God's Word in the Bible as an attribute inhering once and for all in this book as such and what we see before us of books and chapters and verses' (p. 530). om in enige situasie op te tree soos Hy wil (Horton 2011:128).

23.Die vyftigerjare van die vorige eeu sien spanning tussen die behoudende en vernuwende groepe wat mekaar as Ou Orde en Nuwe Orde etiketteer. Die behoudende groep wil na die vroeë Pinksterliturgie terugkeer waar alle lidmate deelgeneem het en die byeenkomste gekenmerk is deur wonderwerke, vrye gebede, getuienisse en die werkings van die Gees soos profesie, spreke in tale en die uitleg van tale. Die Nuwe Orde voorsien 'n erediens wat meer gestruktureerd en georden is (Van Staden 1980:166-167). Die spanning tussen die Ou en Nuwe Orde het slegs in die blanke afdeling van die AGS voorgekom.

24.'n Belangrike voorstander van die Nuwe Orde, pastoor Justus du Plessis, skryf oo die PPK (Van Staden 1980:7): 'In 1958 het hulle van die AGS weggebreek omdat ons, volgens hulle smaak, te veel met die Nederduitse Gereformeerde Kerk verbroeder het. Toe het ons weer vir hulle 'deftig' geraak ... hulle wou meer vryheid hê ... meer losbandigheid sou ek sê.' Die skeuring het ook 'n politieke kleur gehad, met die visepresident, pastoor Gerrie Wessels wat 'n NP-senator geword het, terwyl die visepresident, pastoor Gerrie Wessels wat ' $n$ NP-senator
PPK polities meer behoudend was (Van Staden 1980:8). in ag geneem word, waar mediese hulp tot in die dertigerjare van die vorige eeu minder effektief was. Met die ontdekking van sulfonamied in 1936 en penisillien kort daarna kon bakteriese infeksies met groot sukses behandel word en 'n redelike persentasie siektes hokgeslaan word. Die 'tweede geslag' (Burger 1987:297) kyk anders na die kerk en die samelewing as die 'eerste geslag' wat die beweging begin het, die visioen in hulle harte gehad het en die prys daarvoor betaal het. Burger noem dit ' $n$ historiese waarheid dat die tweede geslag van 'n herlewingsbeweging se entoesiasme, ywer en toewyding afneem. Onder Möller se leiding neem die kerk nie meer openlik standpunt in teen enige mediese ingrype nie. Hierdie standpunt is ook as Nuwe Ordepropaganda beskou en was een van die argumente vir die regverdiging van die kerkskeuring. Die PPK het vir etlike jare geleer dat die gebruik van medisyne neerkom op 'n belydenis van ongeloof in God se krag om te genees en dat dit ' $n$ teken is dat die gelowige afvallig geword het. ${ }^{25}$

Möller (Bosman 1988:23) skryf in die 1964-Jaarboek van die AGS dat goddelike genesing ' $n$ daad van God is wat nie in botsing met die mediese wetenskap gesien mag word nie; dit mag ook nie die plek van die mediese wetenskap inneem nie. Om slegs op gebedsgenesing te vertrou, klink vir Möller (1975:244) aanmatigend en 'n verloëning van die natuurlike wêreld waarin God die mens geplaas het. 'En wie die natuurlike wil verbygaan omdat hy meen om daardeur die bonatuurlike te bereik, is eintlik besig om God, die Skepper van alle dinge, te versoek' (Möller 1975:244). Mediese genesing het nie te make met inmenging in of die betreding van God se wêreld nie, maar met die natuurlike wyse om die afbrekende magte van siekte te beveg (Möller 1975:246). Om na genesing ter wille van die mens se gerief en geluk te soek, sonder die motief van groter toewyding, gehoorsaamheid en ywer om God te verheerlik en sy koninkryk uit te brei, is menslik maar God-onterend. Möller (1975) stel verder:

Dit is in die aksie waar ons Christus as die verrese Heiland vir die mense voorhou, wat ons die flitse van die toekomende heerlikheid, in die vorm van die manifestasies van geestelike gawes gewaar. (bl. 246)

Die verband tussen goddelike genesing en die versoeningsleer wat deur Lake en ander gelê is, word egter nog steeds gehandhaaf. Möller (s.a.:29) sê: 'Goddelike genesing is 'n seën wat op Golgota verwerf is.' Sonde, siekte en dood word saam gegroepeer as die vloek wat oor die gevalle mensdom gekom het, terwyl goddelike genesing deel van die vrug van die versoeningswerk is wat Christus aan die kruis voltooi het.

Die enigste verskil in die versoeningsleer is ' $n$ klein nuanseverskil wanneer die standpunt geformuleer word, naamlik dat die verband tussen sonde en siekte en die kruis en genesing eerder indirek as direk is soos dit in die verlede verkondig is. Die verskeidenheid gevolge van die sondeval

25.In artikel 15 van sy Statement of Faith skryf die PPK (2014): "We believe that divine healing was provided for in the Old and New Testament and is an integral part of the Gospel.' 
bestaan volgens Genesis 3 uit die vervloeking van die slang en vyandskap tussen die slang en die mensegeslag, die moeite van kindergeboorte, en die vrou se ondergeskiktheid aan die man, die vervloeking van die aarde deurdat dit onkruid sal voortbring en die mens hard sal moet werk om 'n lewe daaruit te maak, en die instelling van die dood. Christus bring met sy kruisdood versoening tussen God en die mens; en vir die mens breek die koningsheerskappy van God in 'n herstelde verhouding aan, maar nie ten volle nie. In 'n persoonlike gesprek met Möller (op 03 November 1990) maak hy 'n kwalitatiewe verskil tussen die onderskeie onderdele van die vrug van die sondeval. Die dood is verslaan, maar nog nie ten volle vernietig nie (1 Kor 15). Die mens se verhouding met God is herstel, maar die vervloeking oor die aarde geld nog. In dieselfde sin bestaan daar 'n kwalitatiewe verskil tussen siekte as produk van die sondeval (as tekens of voorloper van die naderende dood) en individuele sonde as produk. Christus speel met die een ten volle klaar, maar die ander een moet soos die dorings en ander onkruid wag vir die volmaakte openbaring van die ryk van God met die wederkoms van Christus. Selfs in die geval van sonde in die lewe van die gelowiges, kom daar nie volledige oorwinning in dié wêreld nie, maar sal die mens moet wag vir die dood voor dit ten volle oorwin sal word, nieteenstaande die inwoning van die Gees in die lewe van die gelowiges.

In hierdie opsig maak Möller (1984:7) 'n onderskeid tussen geloof vir saligheid en geloof vir genesing. Hy meen dat dit op twee onderskeie vlakke funksioneer en kwalitatief van mekaar verskil. Wanneer die twee met mekaar verwar word, kan die siek mens wat nie gesond word nie redeneer dat indien geloof in die geval van genesing nie die nodige verligting gebring het nie, dit verseker ook nie in die geval van saligheid gaan werk nie.

Möller (1975:219) erken dat daar meningsverskil en onsekerheid onder pinksterteoloë oor vele punte rakende genesing bestaan, onder andere oor die verband tussen goddelike genesing en die genadegawes van genesing (1 Kor 12:9), die verband tussen massagenesingsdienste en die rol van die pastoraat asook die plaaslike gemeente in die genesingsbediening, die geïnspireerde bediening teenoor die institusionele bediening van gebedsgenesing en die basis vir goddelike genesing wat deur sommige mense aan die versoeningswerk van die kruis en deur ander aan die genadegawes gekoppel word. Möller meen egter dat die basis in die versoeningswerk bestaan. Hierin stem hy saam met Bruner (1970) wat skryf:

The case for healing is built paradigmatically upon the ministry of Jesus, and theologically is rooted not in the doctrine of the Holy Spirit but in the doctrine of the atonement. (pp. 140-141)

Alhoewel Möller genesing aan die versoening verbind, kry hy dit reg om tog aan die soewereiniteit van God vas te hou. Hy doen dit deur aan dood, siekte en ander vorms van lyding deur die versoeningswerk 'n nuwe betekenis te verleen. Lyding en siekte is nie slegs meer strafmaatreëls oor die sonde van die mens nie, maar dit het ook aan die genade diensbaar geword. Möller (1975) poneer:

Om siek te wees is ' $n$ aanduiding van die gebroke en gevalle mensdom waarvan almal deel is, maar dit staan ook in die teken van die genade waar God ook daardeur die goeie kan bevorder. Elke geval waar siekte deur 'n direkte aanslag van die duiwel veroorsaak mag wees (iets wat heel uitsonderlik is en alleen deur 'n spesiale openbaring geken kan word), is daar goddelike genade om dit òf te oorkom òf te midde daarvan tot eer van God te lewe. (bl. 235)

Die implikasie is dat ruimte gelaat word dat God siekte mag toelaat omdat $\mathrm{Hy}$ 'n doel daarmee dien. Siekte is steeds een van die vrugte van die sondeval, maar dit kan nie aan 'n spesifieke sonde gekoppel word nie, omdat dit met die algemene gebrokenheid en gevallenheid van die mensdom te make het en nie met die partikuliere gevallenheid van die individu nie. Dit veronderstel 'n onderskeid tussen die situasies van die gelowige en die ongelowige, waar God anders met sy kind as met die sondaar handel. Siekte en genesing speel ook verskillende rolle by die gelowiges en die ongelowiges (Gee 1949:110). ${ }^{26}$ In die 'sending'-situasie is wonders ' $n$ bevestiging van die ryk van God. Hulle is tekens wat aandui dat die nuwe orde van die Godsryk deurgebreek het (Verhoef 1966:11). Die genesingsbediening in die gemeente het nie te make met die verkondiging na buite nie. Paulus kon moontlik genoodsaak gewees het om 'n medewerker siek agter te laat (2 Tim 4:20) of self ook siek te wees (Gal 4:13; Verhoef 1966:11).

\section{Implikasies}

Dat die leerstelling van genesing binne die AGS (en die Pinksterbeweging) sekere ontwikkelings in die eerste 50 jaar van sy bestaan vertoon, hou spesifieke implikasies in.

Die eerste implikasie is dat die beweging aanvanklik standpunte rondom die leerstelling geformuleer het en dit ook bybels begrond het, ${ }^{27}$ maar hierdie standpunte is met die tyd aangepas. Die beweging kan dus foute in die teologiese formulering van aspekte van 'n leerstelling begaan, iets wat ook in ander dele van die kerk voorgekom het, byvoorbeeld gedurende die sestiende-eeuse Hervorming toe die RoomsKatolieke formulering van leerstellings verwerp is (vgl. Olson 1999:369-396 vir 'n beskrywing hiervan). Hierdie toedrag van sake moet die Pinksterbeweging nederig en versigtig maak om standpunte te formuleer, omdat die besef daar is dat aanpassings met verloop van tyd gemaak kan word. Die Christelike kerk het met verloop van tyd ook anders oor sekere aspekte begin dink, byvoorbeeld slawerny,

26.Donald Gee van die Amerikaanse Assemblies of God se besoeke aan Suid-Afrika en sy insette in die AGS was van beslissende belang. Hy het die AGS van Januarie
tot April 1934, Januarie tot April 1950 en Julie tot September 1956 besoek. 'Sy tot April 1934, Januarie tot April 1950 en Julie tot September 1956 besoek. 'Sy
gesonde Skrifgebonde leringe het menige Pinksterkerk van gevaarlike slaggate gesonde Skrifgebonde leringe het
gered', meen Burger (1987:379).

27.Of ten minste kon teksverse aangehaal word wat dit bewys het. Vergelyk die bespreking hierbo oor bewysplase as ' $n$ gevaarlike wyse om met die Bybel om te gaan. 
vroueregte, die rol van die vrou in die kerk, menseregte oor die algemeen, asook afsonderlike ontwikkeling as 'n wyse van naasbestaan tussen die onderskeie etniese groepe.

'n Volgende implikasie is dat eerlikheid van die kerk gevra word wanneer agtergekom word dat die leerstelling en die praktyk met mekaar bots. Dan moet die leerstelling ondersoek en die implikasies vir die praktyk nagevors word. Op 'n stadium het die kerk agtergekom dat die genesingsbediening nie effektief is nie omdat lidmate dikwels nie ná gebed gesond geword het nie. Terselfdertyd het die mediese wetenskap se effektiwiteit toegeneem (bv. as gevolg van die uitvinding van penisillien en die ontwikkeling van antibiotika), sodat lidmate al meer daarvan gebruik gemaak het. Die kerk het anders oor die mediese wetenskap se bydrae tot die bevegting van siekte begin kyk. Die belangrike vraag wat gestel moet word, is die volgende: Het die diskrepansie tussen die teorie en die praksis, of die teologie en die pastorale praktyk met die praktyk te doen wat aangepas moet word, of met 'n gebrek aan geloof, of lê die gebrek by die inhoud van die leerstelling wat deur die kerk verkondig word?

Die antwoord wat met verloop van tyd binne die AGS verskaf is om die praktyk te verduidelik, sluit aan by die antwoord wat deur die eeue in die Christelike kerk verskaf is, naamlik dat daar 'n verskil tussen die sendingsituasie ${ }^{28}$ en die situasie in die gevestigde gemeente is. ${ }^{29} \mathrm{Om}$ bybelse gronde vir so 'n onderskeid te vind, is egter moeilik, omdat die situasie in die vroegste kerk wat in die briewe van die Nuwe Testament gereflekteer word, tot 'n groot mate 'n sendingsituasie verteenwoordig eerder as die gevestigde kerk. Jakobus 5:14-16 verwys spesifiek na die praktyk in die gevestigde kerk wat duidelik anders is as die wyse waarop die apostels genesing bedien het (vgl. byvoorbeeld Hand 3:1-10). 'n Argument kan dus uitgemaak word dat die charisma van genesing verband hou met die sendingopdrag van die kerk, terwyl die praktyk in die gevestigde gemeente 'n ander beklemtoning van die leerstelling vereis.

Die gevaar wanneer soteriologie direk aan genesing verbind word, selfs net in 'n kwalitatiewe sin, is reeds genoem. Die gelowige mens kan die reglynige gevolgtrekking maak dat geloof vir genesing nie die effek het wat verwag word nie en dat geloof vir saligheid dan ewe oneffektief kan wees. Die kerk moet eerder nuut daaraan dink dat genesing as 'n eksklusiewe en unieke werk van God beskou word wat Hy op soewereine wyse in die lewe van die individu doen, dat Hy alleen daaroor besluit en dat dit medegelowiges se taak is om siekes te bemoedig en geestelik te versorg, saam vir genesing

28.Met sending word spesifiek verwys na die situasie waar die evangelie verkondig word aan mense wat nog nie daarvan gehoor het nie. Die term word gekwalifisee omdat dit ook ander assosiasies het. Die Pinksterbeweging het tradisioneel na homself as ' $n$ 'sending' of 'beweging; verwys, deels vanweë hulle idee dat hulle 'n dinamiese beweging wil wees wat uitreik na 'n verloregaande wêreld maar ook vanweë 'anti-denomination sentiment' (Burger 1997:190).

29.Proponente van die teorie dat die geestesgawes slegs beperk is tot Jesus (Keener 2011 1:6 noem dat 'n derde van die Evangelie van Markus aan wonderwerke van . 列 2:34 (Hokme 2.34 (Hockema $1966: 16-19)$. "The thrust of this argument is that the purpose of the miraculous gifts was to attest to and thus authenticate the revelation and the incarnation. When that purpose had been fulfilled, the miracles being unnecessary, they simply faded away' (Erickson 1983:893-894; vgl. ook Warfield 1953:6). te bid, terwyl die gebed insluit dat die Here sy wil doen en sy doel bereik. Genesing is die werk van die Gees wat nie mense nodig het nie, maar wel mense mag gebruik soos die Nuwe-Testamentiese gegewens rakende die geestesgawes telkemale verduidelik (Rom 12:6-8; 1 Kor 12:8-11, 28-30; Ef 4:7-11; 1 Pet 4:7-11). Die bediening van goddelike genesing hoort eerder aan die werking van die Gees in die liggaam van Christus en die wêreld (pneumatologies) verbind te word as aan die versoeningswerk, aangesien dit 'goddelike' genesing is, genesing wat die prerogatief van God is. Selfs indien die onderskeid tussen die bediening in ' $n$ sendingsituasie en gevestigde gemeente gehandhaaf word, bly dit die werk van die Gees wat soos die wind waai waar Hy wil (Joh 3:8 verduidelik dat die mens wat uit die Gees gebore is, Hom verteenwoordig en sy wil doen).

Wanneer 'n leerstelling binne 'n kerk ontwikkel, noop dit die kerk om ook na die wyse te kyk waarop dit die Skrif gebruik (hermeneutiek). Die Pinksterbeweging se Skrifbeskouing is op die veronderstelling gebaseer dat die Ou en Nuwe Testament volgens 'n beloftevervullingskema geïnterpreteer word (Archer 2009:136) sodat beloftes wat die moderne situasie pas, net so op die huidige gemeenskap van toepassing gemaak word. Die veronderstelling is dat die moderne Pinkstergemeenskap aan dieselfde belofte en ervarings deel het as wat die bybelse geloofsgemeenskap beleef het (Archer 2009:137). Die belangrike vraag wat gestel moet word, is of daar 'n direkte lyn getrek kan word tussen die ervarings van mense in Jesus en die apostels se bediening en ons moderne tyd. Is dit geldig om op eklektiese wyse te verwag dat sommige ervarings wat in die bybelse tye voorgekom het, in die moderne kerk herhaal sal of moet word? ${ }^{30}$ Kan beloftes aan individue en groepe (die volk Israel) in bybelse tye op ewe eklektiese wyse vir moderne gelowiges toegeëien word, sonder inagneming van die historiese bepaaldheid daarvan asook die ideologiese of teologiese oogmerke wat bepaalde Skrifgedeeltes se inhoud mag bepaal?

'n Laaste implikasie behels dat indien die kerk vind dat belangrike aanpassings in een leerstelling genoodsaak is, dit ook krities na ander leerstellings moet kyk wat uitdagings mag bied, byvoorbeeld die Pinksterbeweging se leerstelling van die imminente verwagtings van die tweede koms van Christus en die gepaadgaande premillenialistiese standpunt wat die wegraping en duisendjarige vrederyk insluit, asook die hoofsaaklik presbiteriale ekklesiologie waarop die kerkordelike reëlings gebaseer word. Dit geld vir alle ander leerstellings; die kerk behoort ruimte te laat vir kritiese nadenke oor die leerstellings met die doel om dit aan die een kant te analiseer in terme van die teologiese apparatuur wat die moderne tyd bied en aan die ander kant, die inligtingsontploffing wat ons dag kenmerk.

\section{Gevolgtrekking}

In hierdie artikel is ontwikkelings binne die wit afdeling van die AGS geskets rakende die verkondiging en praktyk

30.Die argument wat pinkstermense moontlik die meeste hiervoor gebruik, is dat Jesus dieselfde bly en dieselfde doen deur alle eeue heen (Heb 13:8). 
van genesing as verteenwoordigend van dit wat in die Pinksterbeweging gebeur het. Indien die Pinksterbeweging belangrike aanpassings in 'n leerstelling kon maak wat 'n direkte invloed op die bedieningspraktyk uitgeoefen het, onderstreep dit die noodsaak dat ander leerstellings ook onder die loep geneem word om te vra na die bybelse begronding asook die praktiese uitlewing daarvan in die praktyk van die kerk.

\section{Erkenning \\ Mededingende belange}

Die outeur verklaar dat hy geen finansiële of persoonlike verbintenis het met enige party wat hom nadelig kon beïnvloed het in die skryf van hierdie artikel nie.

\section{Literatuurverwysings}

AGS, sien Apostoliese Geloofsending in Suid-Afrika.

Anderson, A., 2003, 'Towards a pentecostal missiology for the majority world', Pape read at the International Symposium on Pentecostal Missiology, Asia-Pacific Theological Seminary, Baguio, Phillipines.

Apostoliese Geloofsending in Suid-Afrika, 1909, Notule van die Uitvoerende Raad, 22 September 1909, AGS Argiewe, Aucklandpark Teologiese Seminarium.

Apostoliese Geloofsending in Suid-Afrika, 1918, Notule van die Algemene Konferensie, 02 April 1918, AGS Argiewe, Aucklandpark Teologiese Seminarium.

Apostoliese Geloofsending in Suid-Afrika, 1919a, Notule van die Algemene Konferensie, 16 Julie 1919, AGS Argiewe, Aucklandpark Teologiese Seminarium.

Apostoliese Geloofsending in Suid-Afrika, 1919b, Notule van die Uitvoerende Raad, 18 Oktober 1919, AGS Argiewe, Aucklandpark Teologiese Seminarium.

Apostoliese Geloofsending in Suid-Afrika, 1919c, Notule van die Uitvoerende Raad, 11 Desember 1919, AGS Argiewe, Aucklandpark Teologiese Seminarium.

Apostoliese Geloofsending in Suid-Afrika, 1921, Notule van die Algemene Konferensie, 01 Augustus 1921, AGS Argiewe, Aucklandpark Teologiese Seminarium.

Apostoliese Geloofsending in Suid-Afrika, 1932, Notule van die Uitvoerende Raad, 23 Maart 1932, AGS Argiewe, Aucklandpark Teologiese Seminarium.

Apostoliese Geloofsending in Suid-Afrika, 1939, 'Mededelings oor die besluite van die Werkersraad', Trooster en Boodskapper van Hoop, Mei, bl. 8.

Apostoliese Geloofsending in Suid-Afrika, 2013, Confession of faith, viewed 01 May 2004, from http://afm-ags.org/confession-faith

Archer, K.J., 2009, A pentecostal hermeneutic: Spirit, Scripture and community, CPT, Cleveland.

Barth, K., 1957,' Church dogmatics', vol. 2, in T.F. Torrance \& G. Bromiley (eds.), The doctrine of God, Part 1, Clark International, Edinburgh.

Bosman, J.E., 1988, 'Teorieë vir 'n genesingsbediening in die Apostoliese Geloo Sending van Suid-Afrika', M.Th.-verhandeling, Fakulteit Teologie, Universiteit van Suid-Afrika.

Bruner, F.D., 1970, A theology of the Holy Spirit, Eerdmans, Grand Rapids.

Burger, I., 1987, Die geskiedenis van die Apostoliese Geloof Sending van Suid-Afrika (1908-1958), Evangelie Uitgewers, Braamfontein.

Burger, I.S. vd M., 1997, 'A historical perspective on the origin of the Apostolic Faith Mission of South Africa', in P.J. Gräbe \& W.J. Hattingh (eds.), The reality of the Holy Spirit in the church: In honour of F.P. Möller, pp. 175-191, Van Schaik, Pretoria.

Burger, I. \& Nel, M., 2008, The fire falls in Africa: A history of the Apostolic Faith Mission of South Africa, Christian Art, Vereeniging.

Chappell, P.G., 1983, 'The Divine Healing Movement in America', Ph.D. dissertation, Faculty of Theology, Drew University.

Choy, L., 1978, Andrew Murray: Beelddraer van God, vert. A. Marais, Dieper Lewe, Silverton.

Dayton, D.W., 1987, Theological roots of Pentecostalism, Hendrickson, Peabody.

De Vries, H.A., 1938a, 'Die Apostoliese Geloof Sending van Suid-Afrika', Trooster en Boodskapper van Hoop 7(20-22), Maart.

De Vries, H.A., 1938b, 'Goddelike genesing, Trooster en Boodskapper van Hoop 7(3), Augustus.

Douglas, W.M., 1926, Andrew Murray: One of God's choice saints, Ambassador, Belfast.

Du Plessis, J., 1984, 'Wat sê die Woord?' Pinksterboodskapper 9(26-27), Februarie.

Erickson, M.J., 1983, Christian theology, 2nd edn., Baker Academic, Grand Rapids.
Gee, D., 1949, Concerning spiritual gifts, Gospel Publishing, Springfield.

Godet, 1936, 'Is the Bible verbally inspired?', Trooster en Boodskapper van Hoop 5(25), September.

Hanekom, A.R., 1985, 'Wonder of vergissing? 'n Teologies-kritiese evaluering van moderne genesingswondere', M.Th-tesis, Fakulteit Teologie, Universiteit van Stellenbosch.

Hoekema, A., 1966, What about tongue-speaking?, Eerdmans, Grand Rapids.

Horn, N., 1984a, 'Pieter Louis le Roux: 'n Vergete pinksterheld', Pinksterboodskapper 9(2-5), Junie.

Horn, N., 1984b, 'John Alexander Dowie: 'n Tydige les uit die verlede', Pinksterboodskapper 9(2-4), September.

Horton, M., 2011, The Christian faith: A systematic theology for pilgrims on the way, Zondervan, Grand Rapids.

Jones, L., 1935, 'Is divine healing for everybody?', Trooster en Boodskapper van Hoop $4(7-8)$, Oktober

Jooste, L.J., s.a., Lewenskets van dr. F.P. Möller, Evangelie Uitgewers, Johannesburg.

Keener, C.S., 2011, Miracles: The credibility of the New Testament accounts, vol. 1 \& 2, Baker Academic, Grand Rapids.

Lake, J.G., 1954a, 'Hiskia se siekte en genesing', gerangskik deur G. Lindsay, Trooster 23(8-9), 21 Maart.

Lake, J.G., 1954b, 'Die genade van goddelike genesing', toespraak gelewer by ' $n$ Konvensie te Chicago, 26 Julie 1920, Trooster 23(6, 15-16), Augustus.

Lake, J.G., 1960, 'Die koperslang', Trooster 30(17-18), April.

Lake, J.G., 1968, 'Kersdag 1910', Trooster 38(5, 14), Desember.

Lake, J.G., 1983, 'Dr John. G. Lake: Soos 'n apostel na Afrika - Historiese opwekking in Suid-Afrika', Pinksterboodskapper 8(32-33), Julie.

Lake, J.G., 1994, John G. Lake: His life, his sermons, his boldness of faith, Kenneth Copeland, Fort Worth.

Langerman, J.L., 1983, 'Apostolic Faith Mission of South Africa: A revitalization of the theological concepts of church ministry'; D.Min. dissertation, Faculty of Theology, Fuller Theological Seminary.

Liardon, R., 1996, God's generals: Why they succeeded and why some failed, Whitaker, New Kensington.

Lindsay, G. (ed.), 1949, The John G. Lake sermons on dominion over demons, disease and death, Christ for the Nations, Dallas.

Lindsay, G. (ed.), 1971, The New John G. Lake sermons, Christ for the Nations, Dallas.

Lindsay, G. (ed.), 1972, John G. Lake: God se gesant na Afrika, vert. H.J. Schepers, Evangelie Uitgewers, Braamfontein.

Lindsay, G. (ed.), 1976, Spiritual hunger, the God-men and other sermons by John G. Lake, Christ for the Nations, Dallas.

Möller, F.P., s.a., En deur sy wonde: 'n Boodskap aan krankes, Evangelie Uitgewers, Johannesburg.

Möller, F.P., 1975, Die diskussie oor die charismata soos wat dit in die Pinksterbeweging geleer en beoefen word, Evangelie Uitgewers, Braamfontein.

Möller, F.P., 1984, 'Rigting in die vernuwing: Die Heilige Gees teenoor die gees van fanatisme' Pinksterboodskapper 9(6-8), Junie.

$\mathrm{Nel}, \mathrm{M} ., 1992$, 'Die leerstelling van goddelike genesing soos dit in die Apostoliese Geloof Sending van Suid-Afrika ontwikkel het: 'n Kerkhistoriese perspektief', D.D. proefskrif, Fakulteit Teologie, Universiteit van Pretoria.

Nelson, P.C., 1936, 'Instruction to those seeking healing', Trooster en Boodskapper van Hoop 5:23, November.

Olson, R.E., 1999, The story of Christian theology: Twenty centuries of tradition \& reform, Apollos, Leicester.

Pinkster Protestantse Kerk, 2014, Statement of Faith, viewed 01 May 2014, from http://www.ppkhoofkantoor.co.za/faith.htm

PPK, kyk Pinkster Protestantse Kerk.

Reidt, W.H., 1981a, Jesus: God's way of healing \& power to promote health: Feauturing the miracle ministry of dr. John G. Lake, Harrison House, Tulsa.

Reidt, W.H., 1981b, John G. Lake: Adventures in God, Harrison House, Tulsa.

Reidt, W.H., 1989, John G. Lake: A man without compromise, Harrison House, Tulsa.

Saayman, W.A., 1993, 'Some reflections on the development of the pentecostal mission model in South Africa, Missionalia 21(1), 40-56.

Stuart, S., 1935, Divine healing, Trooster en Boodskapper van Hoop 4(24), November.

Sundkler, B.G.M., 1976, Zulu Zion and some Swazi Zionists, Oxford University Press, London.

Van Staden, A.J., 1980, Die Apostoliese Geloofsending van Suid-Afrika: Hulle leer getoets aan die Skrif, HAUM, Pretoria.

Verhoef, W.W., 1966, 'Die plek van genesing in die gemeente van Christus', Trooster 36(11-13), Junie.

Warfield, B.B., 1953, Miracles: Yesterday and today, Eerdmans, Grand Rapids.

Wigglesworth, S., 2000, The power of faith, Whitaker, New Kensington. 